\title{
Modern clinical and anamnestical aspects of lichenoid dermatoses
}

\author{
A.M. Bilovol, S.H. Tkachenko, A.A. Berehova \\ Kharkiv national medical university
}

\begin{abstract}
The objective of the work was to study modern clinical and anamnestic features of chronic lichenoid dermatoses.

Materials and methods. Clinical and anamnestic examination of 100 patients with psoriasis and 80 patients with lichen planus ( LP) was carried out. In both study groups, the majority were patients 51-60 years old, the minority - patients 31-40 years old. Among patients with psoriasis, men prevailed in all age groups, among patients with LP, men prevailed in the group of 20-30 years.

Results. In the general gender structure, men prevailed in the group of patients with psoriasis, women prevailed in the group of patients with LP. Comparison of the anamnestic data regarding dermatoses revealed a chronic recurrent nature, characteristic of both psoriasis and lichen planus. According to the to the duration of the disease, among patients with psoriasis, the majority were patients with a long course of more than 10 years, among patients with LP - patients with a history of less than 1 year. In the group of patients with psoriasis, the majority were patients with early onset of dermatosis, in the group of patients with LP - with a late onset after 25 years. Annual manifestations of dermatosis were recorded in the vast majority of patients with psoriasis; in patients with $L P$, annual manifestations of dermatosis were recorded 12 times less frequently. A family history of psoriasis was found 10 times more often than in the LP group. In patients with psoriasis, compared with patients with LP, a greater relative number of long-term forms of dermatosis (38\% of cases versus 22.5\%), and early forms of dermatosis, which occurred before the age of 25 (52\% of cases, versus $26.5 \%$ ) were found. The leading provoking factor among patients with psoriasis was recognized as psychoemotional stress (61\%), and among patients with $L P$, infections suffered the days before (49\%). Also, in patients with psoriasis, obesity and overweight were recorded 5 times more often, cardiovascular diseases - 3.6 times more often, endocrine disorders - 2.4 times more often, concomitant pathology of the digestive system - 1.5 times more often than in patients with LP. At the same time, comorbital chronic infectious states were recorded more often in LP patients than in patients with psoriasis (31.25\% of cases versus $22 \%$ of cases).
\end{abstract}

Conclusions. The revealed results of the clinical and anamnestic characteristics of the studied groups turned out to be homogeneous in terms of age characteristics, heterogeneous in gender characteristics, trigger factors, comorbid pathologies, and multidirectional in terms of duration, manifestations and onset of dermatosis, which requires further study and systematization of key parameters.

Key words: lichenoid dermatoses, lichen planus, psoriasis, anamnesis, clinical picture.

DOI: 10.33743/2308-1066-2021-1-8-12

In recent years, there has been an increase in the incidence of chronic lichenoid dermatoses, the most common of which are lichen planus (LP) and psoriasis, the growth of complicated, torpid, severe and atypical forms, the formation of resistance to conventional therapies [4, 6, 12, 15, $22]$. One of the main modern features of the clinical course of chronic lichenoid dermatoses is comorbidity [9, 12, 17 , 26]. It is known that comorbid disorders worsen the course of the underlying disease, leading to the persistence of the process, disability of the patient, which increases the cost of the health care system and contributes to premature mortality of the working population [1].

The second modern aspect of the clinical course of chronic lichenoid dermatoses is the increase in cases of atypical forms caused by both external, including iatrogenic, and internal factors. Many atypical and difficult to diagnose cases of lichen planus have been described [7]. Recent studies have shown that LP can act as paraneoplasia [10,13] and has certain risks of malignant transformation [3]. Rare polynosological dermatological pathologies have been described, which, along with LP, included Crocker-Adamson follicular keratosis spinulosa, Little-Lussauer syndrome, and systemic lupus erythematodes $[2,14]$.
Among the modern clinical signs of LP the transnosological combinations of LP, in particular Grynszpan Potekaev syndrome, which is a rare triad of symptoms of erosive-ulcerative LP of the oral mucosa, hypertension and diabetes, should be noted [5, 8]. Such polynosological comorbidity is typical and common for psoriasis and indicates common and cross-clinical signs of both lichenoid dermatoses. Polynosological dermatopathologies are also characteristic of the modern clinical course of psoriasis. In recent years, the medical literature has described cases of a combination of psoriasis and vitiligo [27, 28], psoriasis and autoimmune bullous dermatoses, including bullous pemphigoid [20-21].

In recent years, there has been an increase in itching in psoriasis, which reduces the quality of life, disrupts sleep and psychological well-being [11]. This symptom is more characteristic of LP, and such mixing and blurring of the clinical picture of chronic lichenoid dermatoses complicates the differential diagnosis. Isolated cases of same manifestations of psoriasis and LP have also been described [25].

Among the modern aspects of the clinical course of chronic lichenoid dermatoses should pay attention to the significant «rejuvenation» of the pathology [12, 16, 18, 24]. There is a general increase in the incidence of psoriasis 
among children and adults, and the growth of severe and moderate forms of psoriasis among the young population [11, 19, 23].

The objective of the work was to study modern clinical and anamnestic features of chronic lichenoid dermatoses.

\section{Materials and methods}

The study was conducted on two groups of patients with a clinically confirmed diagnosis of «Psoriasis» and «Lichen planus», who were examined and treated in the inpatient and outpatient departments of the MNE «CCDVD-5» of KCC.

The first group entered patients with varying degrees of psoriasis. Assessment of the severity of cutaneous manifestations of psoriasis and the prevalence of the pathological process was performed according to the PASI index (index of area and severity of psoriasis). The second group consisted of patients with LP. All patients considered the analysis of vital functions, the severity of focal neurological and somatic symptoms of the cardiovascular, peripheral and central nervous systems, vascular, muscular and musculoskeletal systems based on the study of the dynamic clinical condition of patients.

The etiology and duration of dermatosis were established on the basis of patient complaints, anamnestic data and clinical examination. Particular attention was paid to the collection of anamnesis for the presence of concomitant pathology. All patients with chronic lichenoid dermatoses underwent clinical blood test, clinical urine test, fecal analysis for helminth eggs, microprecipitation reaction with treponemal antigen and assessment of fasting blood glucose within the Order of the Ministry of Health of Ukraine № 762 of 20.11.2015 (Unified clinical protocol primary, secondary (specialized), tertiary (highly specialized) medical care «Psoriasis, including psoriatic arthropathy» -40 p.), Order of the Ministry of Health of Ukraine № 286 from 07.06.2004 and № 312 and 08.05.2009, as well as the Order Main Department of Health of the Kharkiv Regional State Administration № 436 dated 06.07.2009 according to unified methods. All patients were prescribed examinations and consultations of related specialists according to the indications.

\section{Results}

The total number of examined patients with psoriasis was 100 people, among whom mild severity was diagnosed in 50 people (50\%), moderate - in 38 people (38\%) and severe in 12 people $(12 \%)$. The age range of patients with psoriasis included in the observation group was $20-60$ years, the most numerous group was aged $51-60$ years (29\%). The gender composition of the study group was 64 men (64\%) and 26 women $(26 \%)$. The total number of examined patients with LP was 80 people, including disseminated rash on skin and mucous membranes and/or nails and hair follicles, as well as refractory forms were registered in 40 patients $(50 \%)$.

Localized forms of LP with a rash on the skin of the extremities and/or mucous membranes were diagnosed in 40 patients (50\%). The age range of patients with LP who were included in the observation group was 20-60 years, the most numerous group was aged $51-60$ years (37.5\%). The gender composition of the study group was 36 men (45\%) and 44 women (55\%).

As can be seen from table 1 in both study groups there were male and female patients of four age ranges. In both study groups, the largest number were patients 51-60 years, the smallest 31-40 years. Among patients with psoriasis, men predominated in all age groups, among patients with LP, men predominated in the group of 20-30 years. In the general gender structure, men predominated in the group of patients with psoriasis, women predominated in the group of patients with LP.

As can be seen from table 1 in both study groups there were male and female patients of four age ranges. In both study groups, the largest number were patients 51-60 years, the smallest 31-40 years. Among patients with psoriasis, men predominated in all age groups, among patients with LP, men predominated in the group of 20-30 years. In the general gender structure, men predominated in the group of patients with psoriasis, women predominated in the group of patients with LP.

The duration of psoriasis at the time of participation in the study was 1 month - 30 years. According to the duration of dermatosis, patients were distributed as follows: up to 1 year - 15 people (15\%), from one to five years -26 people (26\%), from 6 to 10 years - 21 people (21\%). Most patients had long-term psoriasis for more than 10 years 38 people (38\%). The onset of psoriasis under the age of 25 was observed in $52(52 \%)$ patients, 48 patients (48\%) had a late onset of dermatosis - after 25 years.

The winter form of psoriasis relative to the seasonality of exacerbations was found in 64 patients $(64 \%)$, summer in 17 patients (17\%), and 19 patients (19\%) suffered from off-season exacerbations. Annual manifestations of psoriasis were registered in 79 (79\%) patients. When studing a genetic history, psoriasis was found in relatives of I and II degree of relatedness in 32 (32\%) patients.

The duration of LP before participation in the study was 2 months -20 years. According to the duration of dermatosis patients were distributed as follows: up to 1 year -31

Table 1. Age and gender characteristics of patients with psoriasis and LP

\begin{tabular}{|c|c|c|c|c|c|c|}
\hline \multirow{2}{*}{$\begin{array}{l}\text { Age } \\
\text { range }\end{array}$} & \multicolumn{3}{|c|}{ Psoriasis } & \multicolumn{3}{|c|}{ LP } \\
\hline & $\begin{array}{c}\text { male } \\
\text { (persons } / \%)\end{array}$ & $\begin{array}{c}\text { female } \\
\text { (persons } / \% \text { ) }\end{array}$ & $\begin{array}{c}\text { total } \\
\text { (persons } / \% \text { ) }\end{array}$ & $\begin{array}{c}\text { male } \\
\text { (persons } / \%)\end{array}$ & $\begin{array}{c}\text { female } \\
\text { (persons } / \% \text { ) }\end{array}$ & $\begin{array}{c}\text { total } \\
\text { (persons } / \% \text { ) }\end{array}$ \\
\hline $20-30$ years & $16 / 16$ & $9 / 9$ & $25 / 25$ & $16 / 20$ & $5 / 6,25$ & $21 / 26,25$ \\
\hline $31-40$ years & $13 / 13$ & $7 / 7$ & $20 / 20$ & $6 / 7,5$ & $7 / 8,75$ & $13 / 16,25$ \\
\hline $41-50$ years & $15 / 15$ & $11 / 11$ & $26 / 26$ & $4 / 5$ & $12 / 15$ & $16 / 20$ \\
\hline $51-60$ years & $20 / 20$ & $9 / 9$ & $29 / 29$ & $12 / 15$ & $18 / 22,5$ & $30 / 37,5$ \\
\hline Total & $64 / 64$ & $36 / 36$ & $100 / 100$ & $36 / 45$ & $44 / 55$ & $80 / 100$ \\
\hline
\end{tabular}


people (38.75\%), from one to five years - 16 people $(20 \%)$, from 6 to 10 years - 15 people $(18.75 \%)$ ), more than 10 years - 18 people (22.5\%). The onset of LP under the age of 25 was observed in 21 patients $(26.25 \%)$ patients, 59 patients $(73.75 \%)$ had a late onset of dermatosis - after 25 years. Annual manifestations of LP were registered in 5 (6.25\%) patients. When studing a genetic history, the LP was found in relatives of I and II degree of relatedness in $3(3.75 \%)$ patients.

Comparison of anamnestic data of dermatoses revealed a chronic recurrent course inherent in both psoriasis and LP. According to the duration of the disease, among patients with psoriasis the largest group were patients with a long course of more than 10 years, among patients with LP - patients with a history of less than 1 year. In the group of patients with psoriasis, the majority were patients with an early onset of dermatosis, in the group of patients with LP - with a late onset after 25 years. Annual manifestations of dermatosis were registered in the vast majority of patients with psoriasis, in patients with LP annual manifestations of dermatosis were registered 12 times less often. Family history in the group of psoriasis was found 10 times more often than in the group of LP.

Clinical forms of psoriasis in the study group were distributed as follows: plaque psoriasis - 82 patients (82\%), guttate psoriasis - 11 patients $(11 \%)$, intertriginous psoriasis -2 patients $(2 \%)$, pustular psoriasis 2 patients $(2 \%)$, palmar-plantar pustulosis -3 patients (3\%). Onychopsoriasis was registered in 24 patients (24\%), psoriatic arthropathy - in 11 patients $(11 \%)$, which accompanied the above clinical forms of skin lesions. Progressive stage of dermatosis was registered in 62 patients with psoriasis (62\%), stationary - in 35 patients (35\%), remission stage - in 3 patients (3\%). The PASI in patients with psoriasis averaged $34.1 \pm 3.7$. In $96(96 \%)$ patients with psoriasis, the rash was disseminated, in 4 (4\%) - localized.

Clinical forms of LP in the study group were distributed as follows. Typical forms of LP were diagnosed in 68 patients (85\%). Among the atypical forms, the hypertrophic form was diagnosed in 7 patients $(8.75 \%)$, the pigmented form in 2 patients $(2.5 \%)$, the atrophic form in 3 patients $(3.75 \%)$, the bullous form in 1 patient (1.25\%). LittleLassuer syndrome was diagnosed in 1 patient (1.25\%). Nail lesions in the form of onychorexis $(6.25 \%)$ and in the form of onycholysis $(2.5 \%)$ were registered in 5 patients. In 74 $(92.5 \%)$ patients the rash was disseminated, in $6(7.5 \%)-$ localized.

The analysis of trigger factors revealed that the onset of dermatosis in 61 (61\%) patients with psoriasis was associated with psycho-emotional stress, in 29 (29\%) - with infectious diseases, in 10 (10\%) - with injuries and surgery. Analysis of provoking factors in patients with LP revealed that the onset of dermatosis was associated with psychoemotional stress in 31 (38.75\%) patients, with a previous infection (acute respiratory infection, pneumonia, bronchitis, pyelonephritis, tonsillitis, etc.) - 39 (48.75\%) patients, 10 patients failed to detect the trigger factor.

A detailed study of the anamnesis in patients with psoriasis, as well as the results of biochemical and instrumental methods of investigation revealed that the frequency of pathology of the hepatobiliary system and pancreas was registered in $27 \%$ of cases, including 14 (14\%) cholecystitis, $3(3 \%)$ pancreatitis, $6(6 \%)$ fatty hepatosis, 4
(4\%) - gallstone disease. Gastrointestinal pathology (gastritis, enterocolitis, malabsorption syndrome) was found in 13 patients (13\%). Pathology of the genitourinary system was registered in $11(11 \%)$ patients. Pathology of the endocrine system was detected in $23 \%$ of patients: diabetes mellitus in 14 patients (14\%) and hypothyroidism in 15 (15\%) patients were dominated diseases. Pathology of the cardiovascular system was registered in 55 patients, including hypertension in 37 (37\%) patients, coronary heart disease in $4(4 \%)$ patients, varicose veins and thrombophlebitis $-8(8 \%)$, atherosclerosis $6(6 \%)$, suffered heart attacks and strokes in 7 (7\%).

Chronic infectious diseases (ENT pathology, bronchopulmonary and urogenital systems, dental infection, viral hepatitis, recurrent herpes, etc.) were found in 22 (22\%) patients. Obesity and overweight were diagnosed in 63 (63\%) patients with psoriasis. Among the concomitant dermatological pathologies, isolated cases of acne, seborrhea, and malassezia have been reported. The study of comorbid pathology in the group of patients with LP revealed pathology of the hepatobiliary system and pancreas in 14 patients (17.5\%), gastrointestinal pathology in 12 patients (15\%), pathology of the genitourinary system in 9 patients (11.25\%), endocrine pathology systems in 9 (11.25\%) patients, cardiovascular diseases in 12 (15\%) patients, obesity and overweight in 12 (15\%) patients, oncopathology in $2(2.5 \%)$ patients. Potekayev-Greenspan syndrome was diagnosed in 2 patients.

The largest group of comorbid diseases were patients with chronic infectious pathology: 5 (6.25\%) with viral hepatitis, 5 (6.25\%) with chronic ENT infection, 6 (5\%) with dental infection, 3 (3.75\%) with persistent herpesvirus infection, 4 (5\%) with chronic gastrointestinal infection, 4 (5\%) with chronic urogenital infection. Dermatological associations were limited to melanocyte nevi.

Thus, it was found that patients with psoriasis, compared with patients with LP have a greater relative number of long-term forms of dermatosis (38\% of cases vs. $22.5 \%$ ), and early forms of dermatosis that occurred before 25 years ( $52 \%$ of cases vs. $26,5 \%$ ). Annual exacerbations of psoriasis in the study group occurred 12.5 times more often than in the group of LP. Family history in patients with psoriasis was registered 10 times more often than in patients with LP.

The leading provoking factor among patients with psoriasis was recognized as psycho-emotional stress (61\%), and among patients with LP - as previous infections (49\%). Also in patients with psoriasis 5 times more often registered obesity and overweight, 3.6 times more often registered concomitant cardiovascular diseases, 2.4 times more often - endocrine disorders, 1.5 times more often - concomitant pathology of the digestive system. At the same time, comorbid chronic infectious conditions were registered more often among patients with LP than in patients with psoriasis $(31.25 \%$ of cases versus $22 \%$ of cases).

\section{Conclusions}

The identified results of clinical and anamnestic characteristics of the studied groups were homogeneous in age, heterogeneous in gender, trigger factors, comorbidities and multidirectional in parameters of duration, manifestations and onset of dermatosis, which requires further study and systematization of key parameters. 


\section{Література}

1. Абрагамович О.О., Фаюра О.П., Абрагамович У.О. Коморбідність: сучасний погляд на проблему; класифікація (повідомлення перше). Львівський клінічний вісник. 2015 № 4(12). С. 56-64.

2. Баткаев Э.А., Чистякова И.А., Устян А.А. Overlap-синдром: системная красная волчанка и красный плоский лишай. Вестник последипломного медицинского образования 15. № 1. С. $26-28$.

3. Большедворская Н.Е., Казанкова Е.М, Белозерцева О.П. Предраковые заболевания. Красный плоский лишай. Вестник научных конференций. 2016. № 4-5 (8). С. 33-35. 4. Заболеваемость и распространенность псориаза в Российкой Федерации / Л.Ф. Знаменская, Л.Е. Мелехина, Е.В.
нерологии. 2012. № 5. С. $20-29$.

5. Красный плоский лишай в составе синдромов: случаи из практики / Н.Н. Потекаев

5. Красный плоский лишай в составе синдромов: случаи из практики / Н.Н. Потекаев, № 15(3). С. $17-23$.

6. Македонова Ю.А. Оптимизация патогенетической терапии больных красным плоским лишаем слизистой оболочки полости рта: дисс. на соиск. д. мед. н., 14.01.14. Волгоград. 2018, рук. 338 с.

7. Молочков А.В., Кильдюшевский А.В, Молочкова Ю.В. Экстракорпоральная фотохимиотерапия типичного и атипичного красного плоского лишая. Альманах клинической ме(йины. 2016. T. 44, № 2. С. 213-220.

8. Молочкова Ю.В., Молочков В.А., Изварина Д.С. Синдром Гриншпана-Потекаєва. 1. Молочкова Ю.В., Молочков В.А., Изварина Д.С. Синдром г

9. Олисова О.Ю., Гаранян Л.Г. Коморбидности при псориазе. Рос. журн. кожн. вен. болезн. 2016. № 6. С. 346-348.

10. Орлова Е.В., Халдин А.А., Севидова Л.Ю. Случай веррукозной формы красного плоского лишая у пациентки с рецидивом рака молочной железы. Российский журнал кожных ского лишая у пациентки с рецидивом рака мол

11. Псориаз: клинико-эпидемиологические особенности и вопросы терапии/ А.Л. Бакулев, Т.В. Фитилева, Е.А. Новоджережкина и др. Вестник дерматологии и венерологии. 2018. Т. 94, № 3. С. 67-76.

12. Святенко Т.В. Червоний плоский лишай: діагностика та лікування: монографія. 12. Святенко Т.В. Червонй
Донецьк: Каштан, 2008. 272.

13. Случай паранеопластического красного плоского лишая, ассоциированного с аденокарциномой прямой кишки / В.А. Молочков, М.А. Бобров, М.А. Амхадова и др. Альманах нокарциномой прямой кишки/ В.А. Молочков, М.А. Бо
клинической медицины. 2016. Т. 44, № 1. С. 107-113.

14. Случай сочетания шиповидного фолликулярного кератоза Кроккера - Адамсона, красного плоского лишая и синдрома Литтла - Лассюэра у юноши 17 лет / Н.А. Слесаренко, С.Р. Утц, А.Л. Бакулев и др. Вестник дерматологии и венерологии. 2014. № 4. С. 68-74. 15. Степаненко Р.Л., Алкаммаз А.М., Степаненко В.ІІ. Раціональна ступінчаста іормо№ 3(70). С. 31-38.

16. Субстантивний погляд на етіологію та патогенез червоного плоского лишаю та його роль в оптимізації лікування / М.Ю. Антоненко, А.М. Парій, Н.А. Зелінська, О.А. Значкова. Современная стоматология. 2016. № 4. С. 16-19.

17. Сызон О.О., Степаненко В.И. Контроль над развитием и течением сопутствующей патологии у больных артропатическим псориазом. Украинский журнал дерматологии, венерологии, косметологии. 2014. № 2 (53). С. 13-26.

18. Childhood Lichen Planus: demographics of a U.S. population / K.E. Walton, E.V. Bowers, B.A. Drolet, K.E. Holland. Pediatric Dermatology. 2010. Vol. 27, No.1. P. 34-38.

19. Clinical and epidemiological characterization of psoriasis and psoriatic arthritis in a multidisciplinary assessment model / R.A. Lopez, G.M. Macias, E.M. Cerda, M.P. Sandoval. Int. J. Clin. Rheumatol. 2018. Vol. 13, № 3. P. 185-192.

20. Coexistence of autoimmune bullous diseases (AlBDs) and psoriasis: A series of 145 cases / C. Ohata, N. Ishii, H. Koga et al. J Am Acad Dermatol. 2015. № 73(1). P. 50-55. URL: https://www.ncbi.nlm.nih.gov/pubmed/25896671 (accessed date 18.11.2020).

21. Dainichi T., Kabashima K. Interaction of Psoriasis and Bullous Diseases. Front Med . 2018. Vol. 5. P. 1-9. URL: https./Www.unboundmedicine.com/medline/citation/ 30135860/Interaction of Psoriasis and_Bullous_Diseases_(accessed date 15.11.2020). 22. Enamandram M., Kimball A.B. Psoriasis epidemiology: the interplay of genes and the environment. J. Invest. Dermatol. 2013. 133 (2). P. 287-289.

Prevalence / R. Parisi, D.P. Symmons, C. E. Griffiths et al. J. Invest. Dermatol. 2013. Vol. 133, № 2. P. 377-385. 24. Khaitov K., Mannanov A., Turakhodjaeva F. Clinical analysis of psoriasis course in children Medical Health and Science Journal. 2010. Vol. 1, Iss. 1. P. 48-50.

25. Ohshima N., Shirai A., Asahina A. Coexistence of linear Lichen Planus and psoriasis in a single patient. Journal of Dermatology. 2011. Vol. 38, No. 12. P. 1182-1184

26. Psoriasis Severity and the Prevalence of Major Medical Comorbidity: A Population-Based Study / H. Yeung, J. Takeshita, N.N. Mehta et al. JAMA Dermatol. 2013. Vol. 149, 10. P. 1173179. URL: http:|//jamadermatol.2013.5015 (accessed date 15.11.2020).

27. The coexistence of psoriasis and vitiligo: a review / Sawchuk M., Spano F., Loo W.J., Guenther L. J Cutan Med Surg. 2012. № 16(5). P. 300-305.

28. Yen H., Chi C.C. Association Between Psoriasis and Vitiligo: A Systematic Review and Meta-Analysis. Am J Clin Dermatol. 2019. № 20(1). P. 31-40.

\section{References}

1. Abrahimovich $\mathrm{OO}$, Fayura OP, Abrahimovich UO. Komorbidnist: suchasniy pohliad na probemu; klasifikatsiia (povidomlennia pershe) (Comorbidity: a modern view at the problem; classification (message first). Lvivskii clinichnyi visnyk. 2015;4(12):56-64. (In Ukr).

2. Batkayev EA, Chistyakova IA, Ustyan AA. Overlap-syndrom: systemnaya krasnaya volchanka i krasniy ploskiy lishay (Overlap syndrome: systemic lupus erythematodes and lichen (in Russ).

. ploskiy lishay (Precancerous diseases. Lichen ruber planus). Vestnik nauchnyh conferenciy. 4. Znam.33-35. (ln Russ).

4. Znamenskaya LPh, Melehina LE, Bogdanova EV, Mineyeva AA. Zabolevayemost i rasprostranyennost psoriasa v Rossiyskoy Federacii (The incidence and prevalence of psoriasis in the

5. Potar

(lichen planus in the composition of syndromes: cases from pr

6 . Makedonova YuA. Optimizaciya patogeneticheskoy terapiyi bolnyh krasnym ploskim liliche 338 p. (In Russ).

7. Molochkov AV, Kildyushevskiy AV, Molochkova YuV. Extracorporalnaya photohimioterapiya tipichnogo i atipichnogo krasnogo ploskogo lishaya (Extracorporeal photochemotherapy for typ(GrinshpanPotekayev Syndrome). Klinicheskaya dermatologlya i venerologiya. 2017;6:50-53. (In Russ). 9. Olisova OYu, Garanyan LG. Comorbitnosty pri psoriaze (Comorbidities at psoriasis). Ros.
Zurn. Ven. Bolezn. 2016;6:346-348. (In Russ).

10. Orlova EV, Haldin AA, Sevidova LYu. Sluchay verrucosnoy formyi krasnogo ploskogo lishaya u patzientki s recidivom raka molochnoy zhelezy (A case of verrucous lichen planus in 2010;1:10-12. (In Russ).

11. Bakulev AL, et al. Psorias: kliniko-epidemiologicheskiye osobennosty s voprosy terapiyi (Psoriasis: clinical and epidemiological features and issues of therapy). Vestnyk dermatologiyi venerologiyi. 2018;94(3):67-76. (In Russ).

12. Svyatenko TV. Chervonui ploskiy lishay: diagnostika ta likuvannya: monographiya (Lichen 12. Svyatenko TV. Chervonui ploskiy lishay: diagnostika ta likuvannya: monographiya (Lichen
ruber planus: diagnosis and treatment: monography). Donetsk: Kashtan, 2008. 272. (In Ukr). 13. Molochkov VA, et al. Sluchay paraneoplasticheskogo krasnogo ploskogo lishaya, associith rectal adenocarcinoma). Almanah klinicheskoy mediciny. 2016:44(1):107-113. (In Russ). 14. Slesarenko NA, et al. Sluchay sochetaniya shipovidnogo folliculyarnogo keratoza
1 rokkera-Adamsona, krasnogo ploskigo lishaya i sindroma Littla-Lussauera u yunoshy 17 let (A case of a combination of Crocker -Adamson follicular spinulosa, lichen acuminatus and Little Lassueur syndrome). Vestnyk dermatologiyi i venerologiyi. 2014;4:68-74. (In Russ).

15. Stepanenko RL, Alkamaz AM, Stepanenko VI. Racionalna stupinchasta hormonalna misceva terapiya psoriazu (Rational step hormonal local therapy of psoriasis). Zhutnal dermatologiyi venerologiyi, cosmetologiyi. 2019;3(70):31-38. (In Ukr).

16. Antonenko MYu, Pariy AM, Zelinska NA, Znachkova OA. Substativniy pohlyad na etiologiyu ta patogenez chervonogo ploskogo lishayu ta yoho rol v optimizaciyi likuvannya (Substantive view on the etiology and pathogenesis of lichen planus and its role in treatment optimization). Sovremennaya stomatologiya. 2016;4:16-19. (In Ukr).

17. Syzon OO, Stepanenko VI. Control nad razvitiyem i techeniyem soputstvuyushey patologiy u bolnyh artropaticheskim psoriazom (Control over the development and course of concomitant pathology in patients with arthropathic psoriasis). Ukrainsky zhurnal dermatologiyi, venerologiyi, cosmetologiyi. 2014;2(53):13-26. (In Russ).

18. Walton KE, Bowers EV, Drolet BA, Holland KE. Childhood Lichen Planus: demographics of a U.S. population.Pediatric Dermatology. 2010;27(1):34-38.

19. Lopez RA, Macias GM, Cerda EM, Sandoval MP. Clinical and epidemiological characterization of psoriasis and psoriatic arthritis in a multidisciplinary assessment model. Int. J. Clin Rheumatol. 2018;13(3):185-192.

20. Ohata $\mathrm{C}$, et al. Coexistence of autoimmune bullous diseases (AIBDs) and psoriasis: A series of 145 cases. J Am Acad Dermatol. 2015;73(1):50-55. URL: https://www.ncbi.nlm.nih.gov/

21. Dainichi T, Kabashima K. Interaction of Psoriasis and Bullous Diseases. Front Med (Lausanne). 2018;5:1-9. URL: https://www.unboundmedicine.com/medline/citation/30135860/ Interaction_of_Psoriasis_and_Bullous_Diseases_(accessed date 15.11.2020).

22. Enamandram M, Kimball AB. Psoriasis epidemiology: the interplay of genes and the enronment. J. Invest. Dermatol. 2013;133(2):287-289.

23. Parisi R, et al. Global epidemiology of psoriasis: a systematic review of incidence and revalence. J. Invest. Dermatol. 2013;133(2):377-385.

24. Khaitov K, Mannanov A, Turakhodjaeva F. Clinical analysis of psoriasis course in children Medical Health and Science Journal. 2010;1(1):48-50.

25. Ohshima N, Shirai A, Asahina A. Coexistence of linear Lichen Planus and psoriasis in a single patient. Journal of Dermatology. 2011;38(12):1182-1184.

26. Yeung H, et al. Psoriasis Severity and the Prevalence of Major Medical Comorbidity: A Population-Based Study. JAMA Dermatol. 2013;149(10):1173-1179. URL: http:|//jamadermatol.2013.5015 (accessed date 15.11.2020)

27. Sawchuk M, Spano F, Loo WJ, Guenther L. The coexistence of psoriasis and vitiligo: a review. J Cutan Med Surg. 2012;16(5):300-305.

28. Yen H, Chi CC. Association Between Psoriasis and Vitiligo: A Systematic Review and MetaAnalysis. Am J Clin Dermatol. 2019;20(1):31-40.

\title{
СУЧАСНІ КЛІНІКО-АНАМНЕСТИЧНІ АСПЕКТИ ЛІХЕНОЇДНИХ ДЕРМАТОЗІВ
}

\author{
А.М. Біловол, С.Г. Ткаченко, А.А. Берегова
}

Харківський національний медичний університет

\section{Резюме}

Мета роботи: вивчення сучасних клініко-анамнестичних особливостей хронічних ліхеноїдних дерматозів.

Матеріали та методи. Проведене клініко-анамнестичне обстеження 100 хворих на псоріаз і 80 хворих на червоний плоский лишай (ЧПЛ). В обох досліджуваних групах найбільшу кількість становили пацієнти віком 51-60 років, найменшу - пацієнти віком 31-40 років. Серед хворих на псоріаз чоловіки переважали в усіх вікових групах, серед хворих на ЧПЛ чоловіки переважали у групі 20-30 років.

Результати. У загальній гендерній структурі чоловіки переважали в групі хворих на псоріаз, жінки - у групі хворих на ЧпЛ. Порівняння анамнестичних даних щодо дерматозів виявило хронічний рецидивний перебіг, притаманний як псоріазу, так і ЧПЛ. За термінами захворювання серед хворих на псоріаз найбільшу групу становили пацієнти з тривалим перебігом (більш ніж 10 років), серед хворих на ЧПЛ - пацієнти з тривалістю хвороби менш ніж 1 рік. У групі хворих на псоріаз більшість становили пацієнти з раннім дебютом дерматозу, у групі хворих на ЧПЛ - з пізнім дебютом (після 25 років). Щорічні маніфестації дерматозу реєстрували в переважної більшості пацієнтів з псоріазом, у пацієнтів з ЧпЛ щорічні маніфестації дерматозу реєстрували у 12 разів рідше. Сімейний анамнез у групі псоріазу виявлявся в 10 разів частіше, ніж у групі чПЛ. У хворих на псоріаз, порівняно з хворими на ЧПЛ, виявлено більшу відносну кількість довготривалих форм дерматозу (З8\% випадків проти 
22,5\%) і ранніх форм дерматозу, що виникли до 25 років (52\% випадків відносно 26,5\%). Провідним провокувальним фактором серед хворих на псоріаз був визнаний психоемоційний стрес (61\%), а серед хворих на ЧПЛ - перенесені напередодні інфекції (49\%). Також у хворих на псоріаз у 5 разів частіше реєстрували ожиріння та надлишкову вагу, у 3,6 раза частіше - супутні серцево-судинні захворювання, у 2,4 раза частіше - ендокринні розлади, у 1,5 раза частіше - супутню патологію органів травлення. Водночас серед хворих на ЧПЛ частіше, ніж у хворих на псоріаз, реєстрували коморбідні хронічні інфекційні стани (31,25\% випадків проти 22\% випадків).

обговорення. Результати клініко-анамнестичної характеристики досліджуваних груп виявилися однорідними за віковими характеристиками, неоднорідними за гендерними характеристиками, тригерними факторами, коморбідними патологіями і різноспрямованими за тривалістю, маніфестацією і дебютом дерматозу, що потребує подальшого вивчення і систематизації ключових параметрів.

Ключові слова: ліхеноїдні дерматози, червоний плоский лишай, псоріаз, анамнез, клінічна картина.

\section{СОВРЕМЕННЫЕ КЛИНИКО-АНАМНЕСТИЧЕСКИЕ АСПЕКТЫ ЛИХЕНОИДНЫХ ДЕРМАТОЗОВ}

А.Н. Беловол, С.Г. Ткаченко, А.А. Береговая

Харьковский национальный медицинский университет

\section{Резюме}

Цель работы: изучение современных клинико-анамнестических особенностей хронических лихеноидных дерматозов.

Материалы и методы. Проведено клинико-анамнестическое обследование 100 больных псориазом и 80 больных красным плоским лишаем (КПЛ). В обеих исследуемых группах большинство составляли пациенты в возрасте 51-60 лет, меньшинство - пациенты 31-40 лет. Среди больных псориазом мужчины превалировали во всех возрастных группах, среди больных КПЛ мужчины превалировали в группе 20-30 лет.

Результаты. В общей гендерной структуре мужчины превалировали в группе больных псориазом, женщины - в группе больных КПЛ. Сравнение анамнестических данных относительно дерматозов выявило хронический рецидивирующий характер, свойственный как псориазу, так и красному плоскому лишаю. Согласно срокам заболевания, среди больных псориазом большинство составили пациенты с длительным течением (более 10 лет), среди больных КПЛ - пациенты с длительностью болезни менее 1 года. В группе больных псориазом большинство составляли пациенты с ранним дебютом дерматоза, в группе больных КПЛ - с поздним дебютом (после 25 лет). Ежегодные манифестации дерматоза регистрировали у преобладающего большинства пациентов с псориазом, у пациентов с КПЛ ежегодные манифестации дерматоза регистрировались в 12 раз реже. Семейный анамнез в группе псориаза обнаруживался в 10 раз чаще, чем в группе КПЛ. У больных псориазом, по сравнению с больными КПЛ, обнаружено большее относительное число длительных форм дерматоза (38\% случаев против 22,5\%) и ранних форм дерматоза, которые возникали до 25 лет (52\% случаев относительно 26,5\%). Ведущим провоцирующим фактором среди больных псориазом был признан психоэмоциональный стресс (61\%), а среди больных КПЛ - перенесенные накануне инфекции (49\%). Также у больных псориазом в 5 раз чаще регистрировали ожирение и избыточный вес, в 3,6 раза чаще - сердечно-сосудистые заболевания, в 2,4 раза чаще - эндокринные расстройства, в 1,5 раза чаще - сопутствующую патологию органов пищеварения, чем у больных КПЛ. В то же время у больных КПЛ чаще, чем у больных псориазом, регистрировали коморбидные хронические инфекционные состояния (31,25\% случаев против 22\%).

обсуждение. Выявленные результаты клинико-анамнестической характеристики исследуемых групп оказались однородными по возрастным характеристикам, неоднородными по гендерным характеристикам, триггерным факторам, коморбидным патологиям и разнонаправленными по длительности, манифестации и дебюту дерматоза, что требует дальнейшего изучения и систематизации ключевых параметров.

Ключевые слова: лихеноидные дерматозы, красный плоский лишай, псориаз, анамнез, клиническая картина.

Відомості про авторів:

Біловол Алла Миколаївна - д-р мед. наук, професор, зав. кафедри дерматології, венерології і медичної косметології, Харківський національний медичний університет; abelovol65@gmail.com

ORCID ID: https://orcid.org/0000-0002-3754-8585

Ткаченко Світлана Геннадіївна - канд. мед. наук, доцент кафедри дерматології, венерології і медичної косметології, Харківський національний медичний університет; tkachenkosve@gmail.com

ORCID ID: $h$ ttps://orcid.org/0000-0001-7681-8464

Берегова Алла Анатоліївна - канд. мед. наук, доцент кафедри дерматології, венерології і медичної косметології, Харківський національний медичний університет; alla096@ukr.net

ORCID ID: https://orcid.org/0000-0002-1781-206X 